УДК 355.233

Данило Шаршаткін

Військова академія (м. Одеса)

ORCID ID 0000-0002-3362-2469

Олександр Розмазнін

кандидат психологічних наук

Військова академія (м. Одеса)

ORCID ID 0000-0002-8575-392X

Юрій Душкін

Військова академія (м. Одеса)

ORCID ID 0000-0003-0449-0863

Володимир Маляганов

Військова академія (м. Одеса)

ORCID ID 0000-0001-8294-5531

DOI: $10.33099 / 2617-1775 / 2021-01 / 352-359$

\title{
ПІДГОТОВКА КУРСАНТІВ ВІЙСЬКОВИХ НАВЧАЛЬНИХ ЗАКЛАДІВ ДО ІНФОРМАЦІЙНО-АНАЛІТИЧНОЇ ДІЯЛЬНОСТІ
}

Обтрунтована спроможність впровадження організащійно-педагогічних умов формування готовності курсантів до інформачійно-аналітичної діяльності під час навчального прочесу. Зроблено висновок про позитивну динаміку зростання рівня готовності курсантів до інформаційно-аналітичної діяльності за критеріальними ознаками.

Ключові слова: інформаційно-аналітична діяльність; курсанти; військовий навчальний заклад; готовність до інформачійно-аналітичної діяльності; організаційно-педагогічні умови; критеріальні рівні; впровадження; експериментальна робота.

Постановка проблеми. Вимоги сучасної держави до випускників військових навчальних закладів обумовлюються не тільки виконанням наказів за командою. Потрібен грамотний фахівець, який володіє навичками використання сучасних інформаційних технологій і систем в професійній діяльності, який здатний нестандартно мислити, бачити кілька варіантів вирішення професійних завдань, здатний оперативно включатися в інформаційно-аналітичну діяльність, що говорить про підвищені вимогах держави до рівня підготовки фахівця, який орієнтований на здійснення інформаційно-аналітичної діяльності.

Сучасні випускники військових навчальних закладів повинні орієнтуватися у величезному потоці інформації, застосовувати нові інформаційні технології, вміти знаходити і використовувати відомості з різних джерел, постійно поповнювати свій інтелектуальний багаж новими знаннями $[3$, с. $78 ; 4]$, володіти багатим арсеналом знань, умінь і навичок, що дозволяють не тільки знаходити, зберігати і обробляти інформацію, а й відтворювати нову; орієнтуватися в інформаційних потоках що стрімко змінюються, продуктивно обробляти їх за допомогою інформаційних технологій та систем; творчо підходити до вирішення завдань, прогнозуючи їх результат. 
Аналіз останніх досліджень і публікацій. Аналіз наукових публікацій показав, що проблема готовності до професійної діяльності $є$ предметом дослідження багатьох вчених: Н. Жиліна, Е. Зарубов, В. Слатін, О. Хмельницький $[3 ; 4 ; 5 ; 8 ; 9]$.

Аналіз літератури 3 проблеми готовності за різноманітними напрямками професійної інформаційно-аналітичної діяльності вказав, що останнім часом цій темі присвячені роботи: О. Дубас, Я. Жарков, Г. Почепцов, О. Савченко $[1 ; 2 ; 6 ; 7 ; 10]$.

Мета статті полягає у дослідженні готовності курсантів військових навчальних закладів до інформаційно-аналітичної діяльності під час навчання та підготовки за напрямками.

Методи дослідження: системний аналіз, порівняння, класифікація, узагальнення та систематизація.

Виклад основного матеріалу. Під поняттям «інформаційно-аналітичної діяльності», розглядається вид пізнавальної діяльності, що сприяє професійному зростанню, шляхом цілеспрямованого вдосконалення інформаційно-аналітичних умінь (пошук, аналіз, критичне оцінювання, творча переробка інформації, інформаційна рефлексія, формулювання висновків i пропозицій) з метою відтворення нового знання для продуктивного вирішення професійних завдань з використанням, в тому числі, інформаційних технологій [7]. Автори пропонують під визначенням готовності курсантів до інформаційно-аналітичної діяльності розуміти - установку особистості на формування мотиваційних та когнітивних компонентів, що спрямована на здійснення інформаційно-аналітичної діяльності, в тому числі, за допомогою інформаційних технологій для успішного виконання професійної діяльності.

3 визначення інформаційно-аналітичної діяльності курсантів військових навчальних закладів випливає, що готовність до інформаційно-аналітичної діяльності в значній мірі залежить від рівня сформованості у курсантів необхідних і достатніх інформаційно-аналітичних умінь, що дозволяють їм ефективно працювати 3 інформацією і застосовувати сучасні інформаційні технології в навчальній, науково-дослідній і практичної діяльності. До таких умінь належать:

- самостійне орієнтування в інформаційному просторі;

- усвідомлення ролі інформації в суспільстві і усвідомлення свого місця в інформаційному середовищі;

- мотивування своїх потреб в інформації;

- здійснення продуктивної інформаційної взаємодії;

- пошук інформації в інформаційно-пошукових системах;

- вміння бачити актуальне в інформаційному потоці;

- варіативне рішення проблем з використанням інформаційних технологій;

- вдосконалення володінь новими інформаційними технологіями;

- здійснення аналізу навчально-професійної діяльності;

- реалізація інформаційно-аналітичної діяльності за допомогою інформаційних технології;

- здатність до самоорганізації, самоконтролю та самоосвіти; 
- здатність до переоцінки наявного досвіду і оновлення наявних знань за допомогою інформаційних технологій [9, с. 46].

Важливо в навчальному процесі виявити комплекс організаційнопедагогічних умов, що забезпечують формування готовності до інформаційноаналітичної діяльності курсантів. Тому 3 групою курсантів була проведена дослідно-експериментальна робота по впровадження організаційнопедагогічних умов.

У експерименті взяло участь 149 курсантів. Мета експерименту полягала у визначенні рівнів готовності до інформаційно-аналітичної діяльності курсантів військових навчальних закладів.

Експеримент проводився 3 курсантами 3 курсу протягом 2018-2019 навчального року, і з ними ж на 4 курсі у 2019-2020 навчальному році. Разом 3 ними, у 2018-2019 навчальному році в експерименті брали участь курсанти 2 курсу, i, вони ж, у 20198-2020 навчальному році, як курсанти 3 курсу. Всього в експерименті взяли участь 149 курсантів, 3 них 75 курсанта відносилося до контрольної групи, 74 - до експериментальної.

Під час роботи автори застосовували підходи, що дозволили виявити організаційно-педагогічні умови формування і визначали критерії (когнітивний, особистий i аналітико-інструментальний) готовності курсантів до інформаційно-аналітичної діяльності (табл. 1).

\section{Критеріальні рівні готовності до інформаційно-аналітичної діяльності курсантів}

\begin{tabular}{|c|c|}
\hline Критерій & Високий рівень \\
\hline Когнітивний критерій & $\begin{array}{l}\text { Знання про інформаційне середовище, інформаційно-аналітичної діяльності } \\
\text { носять цілісний, системний характер, мають процедурну спрямованість. }\end{array}$ \\
\hline Особистий критерій & $\begin{array}{l}\text { Висока інформаційна мотивація, що заснована на розумінні значущості } \\
\text { використання сучасних інформаційних технологій у професійній діяльності; } \\
\text { висока пізнавальна активність, що поєднана } 3 \text { інтелектуально-інформаційною } \\
\text { діяльністю; розвинені інформаційні потреби, що носять безперервний характер. }\end{array}$ \\
\hline $\begin{array}{l}\text { Критерій } \\
\text { діяльності }\end{array}$ & $\begin{array}{l}\text { Інформаційно-аналітичну діяльність виконує самостійно на підставі власного } \\
\text { досвіду; застосовує інформаційні технології та системи для вирішення } \\
\text { професійно-орієнтованих завдань } 3 \text { метою забезпечення ефективності професійної } \\
\text { діяльності; самостійна діяльність спрямована на особистий розвиток. }\end{array}$ \\
\hline $\begin{array}{l}\text { Рефлексивно-ціннісний } \\
\text { критерій }\end{array}$ & $\begin{array}{l}\text { Сформована система особистих ціннісних позицій і настанов, що підпорядковані } \\
\text { етичним нормам під час роботі з інформацією; розвинені навички самоаналізу і } \\
\text { самооцінки, що дозволяє на творчому рівні вирішувати нестандартні і повсякденні } \\
\text { професійні завдання. }\end{array}$ \\
\hline $\begin{array}{l}\text { Аналітично- } \\
\text { інструментальний } \\
\text { критерій }\end{array}$ & $\begin{array}{l}\text { Повною мірою володіє дослідницькими навичками інформаційно-аналітичної } \\
\text { роботи в професійній діяльності; розвинена здатність знаходити і раціонально } \\
\text { використовувати професійно орієнтовану інформацію у професійній діяльності; в } \\
\text { повній мірі використовує можливості автоматизованих інформаційних систем для } \\
\text { отримання, перевірки, аналізу та оцінки інформації під час вирішенні професійно } \\
\text { орієнтованих завдань. }\end{array}$ \\
\hline Кри & Підвищений рівень \\
\hline Когнітивний критерій & $\begin{array}{l}\text { ня про інформаційне середовище, інформаційно-аналітичної діяльності не } \\
\text { ь системного характеру, але виражена процедурна спрямованість. }\end{array}$ \\
\hline Особистий критерій & $\begin{array}{l}\text { Інформаційні потреби розвинені на рівні діяльності, якою займається, відповідно } \\
\text { інформаційна мотивація спрямована на іх задоволення; відносно стійка } \\
\text { пізнавальна активність в рамках предметної області, як наслідок інформаційно- } \\
\text { аналітичну діяльність здійснює, але потрібна допомога. }\end{array}$ \\
\hline $\begin{array}{l}\text { Критерій } \\
\text { діяльності }\end{array}$ & $\begin{array}{l}\text { Інформаційно-аналітичну діяльність виконує за основними блоками алгоритму; } \\
\text { застосовує інформаційні технології та системи для вирішення професійно- } \\
\text { орієнтованих завдань; навички самоосвіти розвинені на предметному рівні }\end{array}$ \\
\hline Рефлексивно-ціннісний & Відносно стійка система особистих ціннісних позицій $і$ н настанов, що \\
\hline
\end{tabular}




\begin{tabular}{|c|c|}
\hline критерій & $\begin{array}{l}\text { підпорядковані етичним нормам під час роботи } 3 \text { інформацією; навички } \\
\text { самоаналізу і самооцінки розвинені на рівні рішення стандартних професійних } \\
\text { завдань. }\end{array}$ \\
\hline $\begin{array}{l}\text { Аналітично- } \\
\text { інструментальний } \\
\text { критерій }\end{array}$ & $\begin{array}{l}\text { Повною мірою не сформовані дослідницькі навички, що не дозволяє виконувати } \\
\text { цілісний аналіз і прогнозувати можливі результати; використовує можливості } \\
\text { автоматизованих інформаційних систем для отримання, перевірки, аналізу та } \\
\text { оцінки інформації під час вирішення професійно орієнтованих завдань. }\end{array}$ \\
\hline Критерій & Граничний рівень \\
\hline Когнітивний критерій & $\begin{array}{l}\text { Знання про інформаційне середовище, інформаційно-аналітичної діяльності } \\
\text { носять розрізнений характер, мають описову спрямованістю. }\end{array}$ \\
\hline Особистий критерій & $\begin{array}{l}\text { Інформаційні потреби не пов'язані з професійною діяльністю, носять хаотичний, } \\
\text { вимушений характер; інформаційна мотивація носить стихійну спрямованість; } \\
\text { нестійка пізнавальна активність як наслідок самостійність під час інформаційно- } \\
\text { аналітичної діяльності знаходиться на низькому рівні. }\end{array}$ \\
\hline $\begin{array}{l}\text { Критерій } \\
\text { діяльності }\end{array}$ & $\begin{array}{l}\text { Інформаційно-аналітичну діяльність виконує суворо за зразком; застосовує } \\
\text { інформаційні технології та системи тільки для вирішення типових завдань; } \\
\text { самостійна діяльність носить епізодичний характер. }\end{array}$ \\
\hline $\begin{array}{l}\text { Рефлексивно-ціннісний } \\
\text { критерій }\end{array}$ & $\begin{array}{l}\text { Слабко сформована система особистих ціннісних позицій і установок, ціннісні } \\
\text { інформаційні фільтри і бар'єри поверхневі; схильний до впливу думки «натовпу»; } \\
\text { не схильний до інформаційної рефлексії, аналізу та інтерпретації інформації. }\end{array}$ \\
\hline $\begin{array}{l}\text { Аналітично- } \\
\text { інструментальний } \\
\text { критерій }\end{array}$ & $\begin{array}{l}\text { Виконує професійно-орієнтовані завдання за аналогією; слабко виражені } \\
\text { дослідницькі навички не дозволяють вирішувати професійно-орієнтовані завдання } \\
\text { з використанням інструментальної обробки інформації; використовує за зразком } \\
\text { автоматизовані інформаційні системи для отримання, перевірки, аналізу та оцінки } \\
\text { інформації при вирішенні професійно орієнтованих завдань. }\end{array}$ \\
\hline
\end{tabular}

Дані констатуючого етапу експерименту з визначення початкового рівня готовності курсантів військових навчальних закладів до інформаційноаналітичної діяльності дозволяють говорити про актуальність даної проблеми.

Оцінюючи рівень готовності курсантів по кожному 3 п'яти критеріїв, автори отримали наступні дані:

- пороговий рівень готовності курсантів за когнітивним критерієм 51\%;

- пороговий рівень готовності курсантів за особистим критерієм 43\%;

- пороговий рівень готовності курсантів за критерієм власної діяльності

$39 \%$;

- пороговий рівень готовності курсантів за рефлексивно-ціннісним критерієм 52\%;

- пороговий рівень готовності курсантів за аналітично-інструментальним критерієм $61 \%$.

Окрім визначення вихідного рівня готовності курсантів до інформаційноаналітичної діяльності по критеріальним ознаками на початковому етапі констатуючого експерименту було визначено вихідний рівень сформованості аналітичних умінь, як елемента, що входить в інформаційно-аналітичну діяльність.

Результати оцінки рівня сформованості аналітичних умінь інформаційноаналітичної діяльності курсантів свідчать про перевагу більш ніж половини курсантів порогового рівня сформованості аналітичних умінь - 56\%.

Дані констатуючого етапу експерименту дозволили авторам обгрунтувати необхідність впровадження в освітню практику організаційно-педагогічних умов, що сприяють формуванню готовності інформаційно-аналітичної діяльності курсантів, що полягають: 
- у збагаченні інформаційно-освітнього середовища інформаційноаналітичної складової, що дозволяе на основі дисциплін інформаційного профілю розвивати інтелектуальну сферу особистості (навички аналізу i самоаналізу), підвищувати рівень інформованості курсантів, їх саморегуляцію, особисте зростання;

- у насиченні змісту дисциплін інформаційного циклу аналітичним аспектом, що дозволяє організовувати відповідну інтелектуальну діяльність $\mathrm{i}$ стиль мислення курсантів здійснювати формування інформаційно-аналітичної компетентності майбутнього офіцера через інформаційно-аналітичну діяльність;

- у мотиваційній спрямованості курсантів 3 оволодіння навичками інформаційно-аналітичної діяльності.

Тому формуючий етап дослідно-експериментальної роботи був спрямований на впровадження та реалізацію вище зазначених організаційнопедагогічних умов, яке здійснювалося на підставі компетентністного підходу, що обумовлює використанням проблемного (вибірки проблемних ситуацій, проблемно-орієнтованих і дослідницьких завдань професійної спрямованості) та інтерактивного навчання (проведення семінарів -конференція).

3 метою підвищення рівня готовності до інформаційно-аналітичної діяльності курсантів в освітній процес була включена навчальна дисципліна «Організація розвідувально-інформаційної діяльності».

Метою викладання навчальної дисципліни $є$ підготовка офіцера військового управління тактичного рівня, який знає основи організації інформаційної роботи в частинах $\mathrm{i}$ підрозділах розвідки тактичного i оперативного рівня ЗС України, знає сучасні способи і методи здобування інформації, може робити ії аналіз, систематизацію, узагальнення, оцінювати важливості та практично складати розвідувально-інформаційних документи, вміти визначати об'єкти розвідки за їх ознаками, способи діяльності військ по характеру їх дій, вести роботу с джерелами розвідувальної інформації, вилучати необхідну інформацію із різних джерел, вести обробку розвідувальної інформації та робити висновки з іiі аналізу, аналізувати та оцінювати воєнногеографічні умови, оперативне обладнання території країн театрів, операційні напрямки, їх ємність, тактичні і оперативні нормативи та їх вплив на ведення бойових дій військами, вміти аналізувати воєнно-політичну обстановку в країнах театрів воєнних дій, прогнозувати її ймовірні зміни та робити висновки для своєї практичної діяльності.

Навчальна дисципліна орієнтована на розвиток інформаційно-аналітичних умінь і навичок курсантів, на підвищення їх інтелектуального рівня розвитку, на формування алгоритмічного стилю мислення, на цілеспрямоване саморозвиток власної інформаційно-аналітичної діяльності та як наслідок розвиток мотиваційної спрямованості по оволодінню навичками інформаційноаналітичної діяльності.

Навчальна дисципліна побудована в основному на проведенні практичних заняттях, мета яких - формування практичних навичок курсантів в області інформаційно-аналітичної діяльності, через освоєння методів i прийомів 
аналізу інформації, складання алгоритмів розв'язання задач, офісного програмування. Заплановані лекційні та семінарські заняття носять проблемний характер навчання, використовується інтерактивні форми проведення занять.

Успішність формування готовності до інформаційно-аналітичної діяльності залежить від цілісності впровадження організаційно-педагогічних умов у навчально-виховному процесі.

Реалізація організаційно-педагогічних умов формування готовності курсантів до інформаційно-аналітичної діяльності, на думку авторів, спрямована на підготовку теоретично грамотного, практико-орієнтованого, мотивованого на оволодіння практичними навичками інформаційноаналітичної діяльності, що сприяє розвитку пізнавальної активності курсанта в контексті підвищення його інформаційно-аналітичної компетентності, що дозволяють в умовах дефіциту або надлишку інформації раціонально здійснювати інформаційно-аналітичну діяльність, допомагають грамотно володіти сучасними інформаційними технологіями в професійній діяльності.

Про спроможності впровадження організаційно-педагогічних умов в навчальний процес можна судити по відсотку курсантів експериментальної групи, що продемонстрували підвищений рівень готовності до інформаційноаналітичної діяльності в усіх перевіряється критеріям.

Висновки та перспективи подальших досліджень. Таким чином, реалізація організаційно-педагогічних умов формування готовності курсантів військових навчальних закладів до інформаційно-аналітичної діяльності під час навчання показала позитивну динаміку зростання рівня готовності по критеріальним ознакам. Курсанти в цілому адаптовані до мінливих реалій навколишнього світу, здатні сприймати, зберігати, відтворювати нову інформацію, ефективно управляти і обробляти інформаційні потоки.

Напрямом подальших досліджень $є$ вивчення досвіду зарубіжних країн у підготовці курсантів до інформаційно-аналітичної діяльності.

\section{ЛІТЕРАТУРА}

1. Дубас О. Інформаційний розвиток сучасної України у світовому контексті. - К.: Генеза, 2004. -380 c.

2. Жарков Я.М., Дзюба М.Т., Замаруєва І.В., ін. Інформаційна безпека особистості, суспільства, держави: Підручник. К.: Видавничо-поліграфічний центр "Київський університет", 2008. - $274 \mathrm{c}$.

3. Жиліна Н.Д. Аналітичні вміння спеціалістів інформаційних технологій: монографія / Н.Д. Жиліна, М.В. Лагунова, Л.Б. Тарєнко: К: КПМУ, 2018. - 115 с.

4. Жиліна, Н.Д. Особливості формування аналітичних вмінь у майбутніх спеціалістів інформаційних технологій / Освітні технології та суспільство. - 2016. - К. 19. - № 4. - С. 364-376.

5. Зарубов, Э.Ф. Психологія професійної освіти: посібник / Э.Ф. Зарубов. - 2-е вид., випр.- Х.: Академія, 2013. -416 с.

6. Почепцов Г. Інформація \& дезінформація / СПб: Ніка-Центр, 2001. С. 108.

7. Савченко, Е.Н. Теоретичні аспекти визначення поняття інформаційно-аналітичної діяльності / Суспільство: Соціологія. Психологія. Педагогіка. - 2019. - №2(58) - К. 91-96.

8. Слатін, В.А. Педагогіка: посібник / В.А. Слатін, И.Ф. Исаєв, Е.Н. Шиянов. - Х.: Академія, 2008. $-576 \mathrm{c}$. 
9. Хмельницький О.О. Інформаційна культура: Підготовка кадрів до інформаційної роботи: Навчальний посібник. - К.: КНТ, 2007. - 200 с.

10. Почепцов Г.Г. Далеке майбутнє, яке бачать військові, уряд і корпорації / Г.Г. Почепцов. - Режим доступу: http://informat.com.ua/uk/daleke-majbutnye-yake-bachat-vijskoviuryadi-i-korporatsiyi

\section{REFERENCES}

1. Dubas O. InformatsIyniy rozvitok suchasnoYi UkraYini u svItovomu kontekstI. - K.: Geneza, 2004. - $380 \mathrm{~s}$.

2. Zharkov Ya.M., Dzyuba M.T., ZamaruEva I.V., In. InformatsIyna bezpeka osobistostI, suspIlstva, derzhavi: PIdruchnik. K.: Vidavnicho-polIgrafIchniy tsentr "KiYivskiy unIversitet", 2008. $-274 \mathrm{~s}$.

3. ZhilIna N.D. AnalItichnI vmInnya spetsIalIstIv InformatsIynih tehnologIy: monografIya / N.D. ZhilIna, M.V. Lagunova, L.B. TarEnko: K: KPMU, 2018. - 115 s.

4. ZhilIna, N.D. OsoblivostI formuvannya analItichnih vmIn u maybutnIh spetsIalIstIv InformatsIynih tehnologIy / OsvItnI tehnologIYi ta suspIlstvo. - 2016. - K. 19. - \# 4. - S. 364-376.

5. Zarubov, E.F. PsihologIya profesIynoYi osvIti: posIbnik / E.F. Zarubov. - 2-e vid., vipr.H.: AkademIya, 2013. $-416 \mathrm{~s}$.

6. Pocheptsov G. InformatsIya \& dezInformatsIya / SPb: NIka-Tsentr, 2001. S. 108.

7. Savchenko, E.N. TeoretichnI aspekti viznachennya ponyattya InformatsIyno-analItichnoYi dIyalnostI / SuspIlstvo: SotsIologIya. PsihologIya. PedagogIka. - 2019. - \#2(58) - K. 91-96.

8. SlatIn, V.A. PedagogIka: posIbnik / V.A. SlatIn, I.F. IsaEv, E.H. Shiyanov. - H.: AkademIya, 2008. - $576 \mathrm{~s}$.

9. Hmelnitskiy O.O. InformatsIyna kultura: PIdgotovka kadrIv do InformatsIynoYi roboti: Navchalniy posIbnik. - K.: KNT, 2007. - $200 \mathrm{~s}$.

10. Pocheptsov G.G. Daleke maybutnE, yake bachat vIyskovI, uryad I korporatsIYi / G.G. Pocheptsov. - Rezhim dostupu: http://informat.com.ua/uk/daleke-majbutnye-yake-bachat-vijskoviuryadi-i-korporatsiyi

\section{PЕЗЮМЕ}

Даниил Шаршаткин

Военная академия (г. Одесса)

Александр Розмазнин

кандидат психологічних наук

Военная академия (г. Одесса)

Юрий Душкин

Военная академия (г. Одесса)

Владимир Маляганов

Военная академия (г. Одесса)

\section{Подготовка курсантов военных учебных заведений к информационно-аналитической деятельности}

Обоснована возможность внедрения организачионно-педагогических условий, по формированию подготовки курсантов $к$ информаџионно-аналитической деятельности $в$ учебном прочессе. Указано о высоком уровне подготовки и склонности курсантов $к$ информачионно-аналитической деятельности по критериальным признакам.

Ключевые слова: информачионно-аналитическая деятельность; курсанты; военное учебное заведение; готовность $к$ информационно-аналитической деятельности; организационно-педагогические условия; критериальные уровни; внедрения; экспериментальная работа. 


\title{
SUMMARY
}

\author{
Danylo Sharshatkin \\ The Odesa Military Academy \\ Oleksandr Rozmaznin \\ Candidate of Psychological Sciences \\ The Odesa Military Academy \\ Yuriy Dushkin \\ The Odesa Military Academy \\ Volodymyr Maliaganov \\ The Odesa Military Academy
}

\section{Preparation of cadets of military educational institutions for information and analytical activities}

Introduction. Increasing the requirements for the quality of professional training of graduates of military educational institutions makes it possible to talk about the need for fundamental training in theoretical and practical orientation for the implementation of research, information and analytical and innovative activities.

Purpose. Training of a competitive specialist who effectively implements information and analytical activities is associated with the readiness of graduates to use modern information technologies and systems in their professional activities. Therefore, it is important in the educational process to identify a set of organizational and pedagogical conditions that ensure the formation of readiness for information and analytical activities of cadets, and increase the efficiency of the educational process.

Methods. The authors of the article on the basis of the concept of "information and analytical activities" note that the readiness for information and analytical activities largely depends on the level of formation of necessary and sufficient information and analytical skills of cadets; offer levels and criteria for determining the readiness of cadets of military educational institutions for information and analytical activities.

Results. The article shows the data of a specific stage of the experiment that determines the initial level of readiness of cadets for information and analytical activities, which allows us talking about the relevance of this problem.

Originality. The authors indicate some aspects of the implementation of organizational and pedagogical conditions for the formation of the readiness of cadets for information and analytical activities in the educational practice of a military educational institution.

Conclusion. The article reflects the data on the ability to implement organizational and pedagogical conditions for the formation of cadets' readiness for information and analytical activities during the educational process, based on which the conclusion has been made about positive dynamics of growth of the level of cadets' readiness for information and analytical activities on the criteria basis.

Key words: information and analytical activities; cadets; military educational institution; readiness for information and analytical activities; organizational and pedagogical conditions; criterion levels; implementation; experimental work. 